\title{
The Interaction of Social, Educational and Religious Institutions in a Postsecular Society*
}

\author{
Olga Chistyakova \\ Faculty of Humanities and Social Sciences \\ Department of Social Philosophy \\ Peoples' Friendship University of Russia (RUDN University) \\ 6 Miklukho-Maklaya Street, Moscow, 117198, Russian Federation \\ E-mail: Olgachis@Yandex.Ru
}

\begin{abstract}
The article substantiates the necessity of interaction among social institutions and formal organizations of traditional religions in terms of secular processes in the Russian society. The idea of rationalization of relations of religious institutions with educational institutions is underway. The author shows the contradictory tendencies of a postsecular society, as it is accompanied by the actualization of religious consciousness, increasing attention to different religions and desire for religious self-identification along with the ethnic, civil and cultural ones. The article focuses on the need for the inclusion of philosophical and religious subjects in the education process of the Russian higher education for an in-depth study of religious processes and religious institutions.
\end{abstract}

Keywords-Secularization; post-secular society; educational institution; social institution; rationalization; intercultural dialogue

\section{INTRODUCTION}

The actualization of religion and religious organizations in their interaction with social institutions, including the educational institutions of the Russian Federation, seems to be very important. We should note, that we are not referring to any particular religion or a specific church. We are talking about religion in a philosophical sense, as a social phenomenon, which increasing significance seems obvious, and it's ethically correct usage can bring positive content in a solution of some humanitarian issues of our time.

The religious sphere, dealing with an absolute transcendent object and not aspiring to an excessive structural regulation of a subject's moral experience, as the interrelation of ecclesiastic and personal, quite harmoniously restores the individual spiritual life.

Despite the emerging secularization trend of social and cultural spheres, religion intensively starts stepping into individual's personal history displacing to some extent severe regulation forms of bureaucratic regulatory control, declarative political activity, endless coils of all sorts of

*This paper was financially supported by the Ministry of Education and Science of the Russian Federation on the program to improve the competitiveness of Peoples' Friendship University (RUDN University) among the world's leading research and education centers in the 2016-2020 (The Agreement number 02.A03.21.0008). reforms and innovations with the new "game rules" ( $\mathrm{Z}$. Bauman), which nobody expects and which people should follow anyway.

\section{SECUlAR SOCIETY AND THE NEED FOR ITS RATIONALIZATION}

Social life today is getting more and more akin to "the society of the spectacle" (G. Debord) with the increasing trends of dissolving the unique personality traits and unification of the individual foundations, the deinstitutionalization processes of the social institutions of the late modernity, multiplied by the influence of media and creation of mediatized illusory reality, perceived by an individuals as true and objective. The aforementioned characteristics of society are amplified by the loss of a sense of stability and security of life. All this gradually leads to the displacement of the sacred forms of civilization and of spiritual existence into the background.

Under described circumstances religion inevitably occupies the field left free, i.e. the personal space of a contemporary human lost his basis and forced to submit to both external and internal factors of a sheer being.

«Awareness of the current state of social affairs reminds us that religion should not be forced out (or underestimated) from the sphere of social and cultural life, especially from the sphere of the educational process of each person. Religion fills a strong place not only in transcendental but in real social life - that should be recognized even when arguing with a secular or un-churched individual. However, one should be able to see positive in religion, the significant value that religion and religious belief can bring to the society development and to the cultural and educational selfidentity». [1; P. 1192].

21st century, unfortunately, presents the lots of facts when religion may be judged as a factor fueling wars, conflicts, acts of terror. Is it really so? Does religion contribute to the tension, dislike of the other ethnic cultures, or vice versa, does it anticipate the social violence and conflicts, establishing peaceful and tolerant interreligious and ethnocultural relations? 
Let us denote the thesis in connection with the issues raised above. The most important and urgent today is to rationalize the relations among religious organizations and social institutions of the Russian Federation, primarily with the educational institutions, which involves the inclusion of religion in social functioning on the same rational basis [2].

Legally registered by the authorities religious structures, organizations, and unions are to be considered as a promising spiritual power while establishing civilized relations in society, and, most importantly, as a modern social institution, able to prevent the manifestation and implementation of the various social and ethnocultural conflicts, and to reduce consequences, if they occur. A rational approach suggests that the dialogue of society and religion is inevitable. Organizations and unions of different religions should be involved into the real social and humanitarian processes in Russia. Let us emphasize, that we are talking about cooperation in humanitarian, educational and cultural spheres, the help of the churches in the social field and in the fields, where the conflicts and social contradictions are brewing, and not about the political, authoritative, regional municipal structures.

Theoretical and moral fundamentals of religion a priori contradict the meanings of violence, social destruction, and exactly because of that they contribute to the process of rationalization of social life basing on a peaceful and free existence of people. Religion is not that far from rationality, as it is often implied.

In the context of the Church's anxiety expression for the growing irrationality of life, the Pope Benedict XVI's lecture at Redensburg University in 2006 at a meeting with the German scientists and humanitarians is significant.

Pope's lecture was dedicated to the relations between faith and reason and to the call for a return of rationality to the modern world. Benedict XVI emphasized that contemporary "...fundamental decisions made about the relationship between faith and the use of human reason are part of the faith itself" [3]. Faith and reason must come together in a new way, and if society overcomes successfully "the self-imposed limitation of reason to the empirically falsifiable" [3], then the new horizons for reason and society will be opened.

Benedict XVI tried to highlight the spiritual sphere as an actual object of rational comprehension. It may be noted that all of the aforementioned has already taken place in the history of philosophy and theology, to recall the rationalist proofs of God's existence attempted by medieval scholastics. It seems, however, that Benedict XVI intentionally attracts the attention of contemporaries to the fact that rationality remained in the distant past, reason as methodological theological tool and as the basis of modern society no longer plays a major role and lost its significance. Hence the fears of expanding the scopes of violence, conflicts, revolutions, forced actions of some nations over the others.

"The Head of the Catholic Church spoke in his lecture of the need of returning theology into the universities. Theology, from his point of view, belongs to the universities and wide- range scientific dialogue in contemporary culture, but as a discipline

belief questioning rationality of and interconnecting therefore a variety of cultures. Pope Benedict XVI believes that the Western world departed from the Greek rationality and from the Greek philosophizing spirit based on reason. This rationality is a world culture's achievement and should be returned to the social life" [1; P. 1194].

Professor of Philosophy, the Slovakian theologian P. Dancak emphasizes the importance of the Benedict XVI's speech, reflecting a deep understanding of the modern state of religions and the Western cultures, found rather in a clash, than in a tolerant and peaceful cooperation. This is partly due to the secularism of the modern society and the deepening post-secularity. Yet Benedict XVI, who spoke at the University as the Professor, “... considers Christian faith and Western rationality to be two partners in a quest to answer questions emerging from the transcendence of man... It requires the correlation of religion and reason, as the supervisory authority of critical reason is summoned to reveal the pathology of faith (religious fundamentalism), and faith, on the other hand, is supposed to help Christians in their prophetic mission to convict the restriction reason of being irrational, for instance looking at absolute categories, such as the right to life, through the lens of utilitarian profit. Reason and truth are summoned to the dialogue in order to get cleansed and revived" [4; P. 680].

Philosopher P. Dancak rightly emphasizes that only the rational dialogue of faith and reason can universalize the world, enable a person to understand to comprehend it on the basis of a balance between faith and reason, given the advances and the conditions of modernity. This rationality as the achievement of culture is to be returned to the sphere of social existence.

We should note that theology has made its return to the Russian universities, initially in the form of specialties included in the nomenclature of the Ministry of Education and Science, then as an educational program for the bachelors. To some extent, in our view, this fills the void between society, public structures, and religious organizations. The taken step is rational in its essence, as for the several years there has been a training of qualified specialists in the field of religion studies, theological reflection and comparative analysis of religions. Thus a constructive context is provided by the discourse of the interaction of the religious organizations and educational institutions, structures of civil society and denominations. This discourse concerns the discussion of the social and cultural spheres and excludes politics.

Contemporary Russian society, just like many Western countries, witnesses secularization processes with obvious characteristics of technocratization and the manipulative influence of mass media [5]. The formation of such societies is accompanied by the transformational changes to a complex but de-institutionalized integrity, reinforced by the crisis of cultural identity and possibilities for personal identification in multicultural societies. However, the problems, related to ethnocultural and religious identities, 
inevitably lead to crises not only in the structures of the social institutions but also in the very religious organizations of the traditional religions and denominations [6].

\section{POSTSECULAR SOCIETY, EDUCATION AND RELIGIOUSNESS}

The current epoch is sometimes referred to as postsecular, expanding the typological characteristics of the irreligious modern world. The Canadian philosopher $\mathrm{C}$. Taylor has written one of the most profound books on the case - "A Secular Age", where he identifies the following essential characteristics of the post-secular era: secularization of social space, the decline of faith and religious practices, the strengthening of unbelief as the most common and viable choice of a person in certain social and cultural conditions [7].

According to C. Taylor, in the era of modernity, everything, belonging to the religious sphere - liturgy, rites, ceremonies, worshipping, congregations - was concentrated in the sphere of a church. Nowadays such a union is almost impracticable, and the people may reach their religious aspirations in a variety of religious organizations. The search for a personal identity in the late 20th century accelerated the division of the religious experience and church. The contemporary world is no longer a civilization where all the aspects of life are influenced by faith. Therefore, a postsecular society made the unity of diverse facets of the religious life impossible.

On this basis, the Canadian philosopher stresses, that the greatest challenge for the church of the modern era consists in the union of people, representing the aforementioned life orientations and aspirations, different views and religions inside one sacramental (sacred) union [8. P. 26].

This kind of goal is also relevant to a postmodern secular society, which fragmentation and segmentation do not allow a person to feel the depth, stability, security. Our contemporary world is multipolar, diverse, riddled with the construction of alternate ways of social and personal lives, including the religious one. The obsolete forms of social are gradually fading away and the new institutions come in; that is being differently perceived by the religious and nonreligious people. For a secular person this is a call of time, expectation of a change, hope for a radical shift. This challenge of modern society begets a variety of life orientations, perspectives, cultural and civic identities, religious experience - everything, that we call pluralism.

It would seem that in a post-secular society faith, personal religious identity would inevitably cease to exist. Yet, we witness the opposite process. "... along with the secular processes, there is a completely opposite trend in a society. The emerging social institutions, communities, and social groups do not exclude the existence and even the actualization of theology, religious diversity and the strive of modern people for religious self-identification along ethnic, civil and political ones" [6. P. 45].

We are convinced, that the mentioned objective transformations should be considered in the education process in the Russian state educational institutions. After all, the spiritual and cultural components of the current youth may in the nearest future affect largely the establishment of civilized relations among the diverse ethnic groups of Russia as well as among the religious associations and organizations, officially operating in the country. The values of different peoples of the Russian Federation must be in the same cultural-axiological and legal fields and be recognized as equal to each other [9]. This position should be formed within the youth, who are to work for peace in our multicultural and multireligious state.

In this context, we see a rational kernel in lecturing special religious disciplines from the point of their philosophical and cultural meaning in the curricula of the higher education. The modern state of the Russian education is still in the process of reformation and it should take into account all the actual problems of our society. The introduction to the higher education the special courses of philosophical-religious nature, could make a constructive contribution to the formation of the values, spirituality, deep ideological positions among students and deepen their knowledge in the fields of history and theory of religious traditions. It is appropriate in this respect to cooperate with theologians and representatives of the traditional religions having an experience in lecturing and research.

\section{CONCLUSION}

In philosophical terms, religion has an anthropological essence, reflecting the spiritual potential of each person, and therefore contributing to the education of an integral person. A postmodern individual, somewhere tired of secularism, should build his existence on the basis of rational selfrealization along with something Absolute: ideas of good, peace, tolerance, humanism, moral values, giftedness [10, 11]. The function of religion is comparable with the linguistic function - religious relations allow a huge number of people to communicate, interact and share their moral and spiritual needs and preferences. Religion is a special mean of communication and, surely, it has its audience. Traditional religions broadcast certain moral and sacral information and modern society, especially in the form of the educational institution, may use it for the constructive purposes.

Religious anthropology justifies the understanding of an individual in a holistic perspective, not only in a soteriological doctrine but in immediate earthly existence. That is why the integrity of an individual is the subject of rational cognition for both philosophy and theology. We are convinced that philosophical and anthropological essence of religion with its tendency towards rationalism must now come to the fore of scientific discourses and become an object of professional training in the higher education.

\section{REFERENCES}

[1] Chistyakova O. Rationalization of Contemporary Culture and Education in the Context of Religious Resistance to Violence // Proceedings of the 2016 International Conference on Arts, Design and Contemporary Education. (ICADCE 2016). Advances in Social 
Science, Education and Humanities Research. Paris: Atlantis Press, 2016. Volume 64. P. 1192-1198.

[2] Chistyakova O.V. Violence and Religion as Social Phenomena of Contemporaneity (Philosophical Anthropological Context) // Bulletin of Peoples' Friendship University of Russia. Series Philosophy. 2015, № 1. P.116-136.

[3] Lecture of the Holy Father Benedict XVI «Faith, Reason and the University Memories and Reflections. Meeting with the representatives of science. Aula Magna of the University of $\begin{array}{llllll}\text { Regensburg, } & 12 & \text { September } & 2006\end{array}$ http://www.vatican.va/holy_father/benedict_xvi/speeches/2006/septe mber/documents/hf_ben-xvi_spe_20060912_universityregensburg_en.html

[4] Dancak P. The Cristian Universalism, Globalization and Tolerance in the Thought of Joseph Ratzinger-Benedict XVI // Proceedings of the $20163^{\text {rd }}$ International Conference on Education, Language, Art and Inter-cultural Communication (ICELAIC 2016). Advances in Social Science, Education and Humanities Research. Paris: Atlantis Press, 2017. Volume 40. P. 678-682.

[5] Chistyakov D. Social Dimension of Media Space in the Age of Postmodernity. In the Context of Objective Knowledge Obtainment // Proceedings of the 2016 International Conference on Arts, Design and Contemporary Education. (ICADCE 2016). Advances in Social Science, Education and Humanities Research. Paris: Atlantis Press, 2016. Volume 64. P. 297-300.

[6] Chistyakova O.V. Society and Religion in a Postsecular Age: Theoretical Approaches and Empirical Interaction // Bulletin of Peoples’ Friendship University of Russia. Series Philosophy. 2016, № 2. P. 43-51.

[7] Taylor, C. A Secular Age. Cambridge, 2007. Belknap Press of Harvard University Press.

[8] Taylor, C. Authenticity: The Life of the Church in a Secular Age // Renewing the Church in a Secular Age: Holistic Dialogue and Kenotic Vision. March 4-5, 2015. Pontificia Universita Gregoriana, Rome. A Joint Conference with Council for Research in Values and Philosophy and the Patronage of Pontifical Council for Culture. Rome, 2015.

[9] Belov V. Karagod J. The Crisis of European Culture in the Works of Russian Philosophers of the Twentieth Century. Around the Ideas of Spengler // Proceedings of the $20163^{\text {rd }}$ International Conference on Education, Language, Art and Inter-cultural Communication (ICELAIC 2016). Advances in Social Science, Education and Humanities Research. Paris: Atlantis Press, 2017. Volume 40. P. 692-696.

[10] Ponizovkina I.F. Spiritual and Moral resources of Humanity and Humanism //Axiology of culture in the Context of the Challenges of the Modern World. Collection of the Works following the 1st International Scientific-Practical Conference. M., Professional science. 2016. P. 102-109.

[11] Ivleva M., Bagramiants N., Ivlev V., Oseledchik M. Methodological Principles of the Study of the Philosophical Foundations of Psychological Conceptions of Giftedness_// Proceedings of the 2016 $3^{\text {rd }}$ International Conference on Education, Language, Art and Intercultural Communication (ICELAIC 2016). Advances in Social Science, Education and Humanities Research. Paris: Atlantis Press, 2017. Volume 40. P.48-52. 